\title{
W poszukiwaniu idealnych Słowian - o wojowniczości i pacyfizmie jako cechach charakteru narodowego $w$ dociekaniach polskiej historiografii w XIX wieku
}

\author{
PIOTR BOROŃ \\ Instytut Historii, Uniwersytet Ślq̨ski, Katowice, Polska
}

In search of perfect Slavs - about belligerence and pacifism as national traits in the investigations of Polish historiography in the $19^{\text {th }}$ century

Abstract: The article presents the formation of two different stereotypes of the ancient Slavs - as a warlike people and pacifist. Based on the Polish historiography of the nineteenth century, it was shown how the appropriate stereotype was used in the historiographic or literary representation of the ancient Slavs. The starting point for the consideration of many historians were numerous historical sources from the $6^{\text {th }}-7^{\text {th }}$ century, showing the Slavs as a belligerent, as well as one information about the peaceful attitude of this people. And it was the message of Theophylact Simocatta that won the recognition of many researchers living in the $18^{\text {th }}$ and $19^{\text {th }}$ centuries, who inscribed it in the romantic vision of Slavs based on J. G. Herder's historiosophy. The article refers to opposite theories of Alexander Sapieha or Jan Paweł Woronicz. An attempt was also made to reconcile two opposing visions of the ancient Slavs in the theory of conquest, commonly accepted in the $19^{\text {th }}$ century.

Keywords: Historiography, Slavs, national stereotypes, theory of conquest.

DOI: https://doi.org/10.24040/ahn.2020.23.02.131-146

Stosunek wczesnośredniowiecznych Słowian do wojny i pokoju jest i pozostanie dla nas nieznany. Trudno bowiem wnioskować na podstawie tekstów spisywanych przez obcych, niesłowiańskich pisarzy, najczęściej słabo znających ten lud. Pomimo to jednak, od wielu lat funkcjonuje przekonanie o pewnych wzorcowych, wojennych bądź pokojowych postawach (żeby nie mówić o etosie) Słowian. Problem, który pragnę tu przedstawić nie dotyczy miejsca wojny i pokoju w świecie wyobraźni słowiańskiej czy w sposobach postępowania. Takie poznanie jest dla nas niedostępne. Dostrzegamy jednak ogromną ilość wypowiedzi na ten temat, tworzących pewne przeciwstawne sobie, literackie, czy też historiograficzne obrazy Słowianina - raz wojownika, innym razem miłośnika pokoju, czyli pacyfisty.

Problem wojowniczości, czy pacyfizmu Słowian pojawia się w większości charakterystyk, zarówno tych tworzonych przez pisarzy śre- 
dniowiecznych, jak też badaczy średniowiecza. We współczesnej nauce kwestia ta nie jest już rozpatrywana, co nie znaczy, że w świadomości potocznej nie funkcjonuje pewien stereotypowy obraz wzorcowego Słowianina. Takie stereotypowe postrzeganie Słowian widzimy, co najzupełniej naturalne, w średniowieczu. Co najciekawsze, niemal identyczny, ale doprowadzony do skrajności, sposób widzenia Słowian pojawił się w nowoczesnej historiografii, czyli od drugiej połowy XVIII wieku i trwał do wieku dwudziestego, podlegając zmianom i modyfikacjom. Nie wynikały one jednak z postępu badań naukowych, lecz ze zmian w zapotrzebowaniu współczesnych. Inaczej mówiąc, problem wzorca wojownika czy miłośnika pokoju nie dotyka Słowian rzeczywistych, lecz wyobrażonych i przedstawionych. Rzecz więc dotyczyć będzie nie historii, ale naszych o niej wyobrażeń czy złudzeń.

Teksty greckich, niemieckich i arabskich pisarzy są na ogół dość zgodne co do nastawienia Słowian do wojny - są oni jej miłośnikami i nieźli z nich wojownicy. 0 ich umiejętnościach wojennych pisał Jan z Efezu u schyłku VI wieku, że „przeklęty lud Słowian” wtargnął do Hellady, Tesalii i Tracji, zniszczył tamtejsze miasta, i o dziwo tam pozostał. Mieszkają i siedzą spokojnie (niezagrożeni) w ziemiach Rhomajów bez troski i strachu, plądrując i podpalając, bogacąc się i przywłaszczając sobie złoto i srebro, tabuny koni i mnóstwo broni; a nauczyli się prowadzić wojnę lepiej niż Rhomajowie. ${ }^{1}$ Słychać tu swoiste zdziwienie nie tylko weszli i złupili kilka cesarskich prowincji, ale jeszcze w nich pozostali, a nie widać szansy na ich pokonanie. Umiejętności wojenne musieli mieć zatem znaczne, a pokój chyba nie był dla nich najcenniejszy. W mniej więcej tym samym czasie w Bizancjum powstał traktat o taktyce, autorstwa tak zwanego „Pseudo-Maurycego”. Przedstawiono w nim bardzo szczegółowe informacje o Słowianach, a przede wszystkim o sposobach walki z nimi. Wskazano także, jak wielkie problemy miała armia bizantyńska w walkach ze Słowianami.

O zdolnościach wojennych Słowian informuje nas Prokopiusz z Cezarei, opisując bitwę podobną do słynnego starcia pod Termopilami. Oto w czasie wojen Bizancjum z Gotami w Italii (547 rok), wódz Rhomajów, Tulianus „zebrawszy wieśniaków, strzegł najwęższego przejścia, aby przeszkodzić wrogom wtargnąć do Lukanii. Razem z nimi straż pełniło 300 Antów, których wcześniej postawił tam Jan na prośbę Tulianusa. Barbarzyńcy ci zdolni są do walki, szczególnie w trudnym terenie. Gdy Totilla się o tym dowiedział, uznał, że nie jest konieczne wysyłanie tam Gotów; zebrał wielu wieśniaków, dodając im kilku Go-

\footnotetext{
${ }^{1}$ JAN Z EFEZU. Historia kościelna, cap. VI, roz. 25. Tłumaczenie PLEZIA, Marian (ed.): Greckie i Łacińskie źródła do najstarszych dziejów Słowian, cz. 1 (do VIII w.). Kraków : Polskie Towarzystwo Ludoznawcze, 1952.
} 
W poszukiwaniu idealnych Słowian - o wojowniczości i pacyfizmie ...

tów, i rozkazał podjąć próbę zdobycia tego przejścia wszelkimi siłami. Kiedy doszło do spotkania, wywiązała się walka, Antowie jednak dzięki swemu męstwu, a także dlatego, że trudny teren im sprzyjał, wraz z wieśniakami z otoczenia Tulianusa zmusili wrogów do ucieczki". ${ }^{2}$ Owych 300 Antów jawi się tu niemalże jako 300 Spartan walczących z Persami. Trudno powiedzieć, czy Prokopiusz nawiązywał do tej tradycji. Na pewno starał się umniejszyć znaczenie tego zwycięstwa, sugerując brak po drugiej stronie liczniejszych oddziałów gockich. Totilla wysłał tylko wieśniaków. Zauważmy jednak wyraźne wskazanie wojowniczości, czy po prostu przekonanie o dobrej wojskowej postawie Słowian.

Nie jedyny to przypadek informacji o zamiłowaniu do wojny, właściwemu temu ludowi. Menander, zwany Protektorem, opisując konflikt Słowian z Awarami, wywołany żądaniem od Słowian trybutu, przekazał informację o dumnej odpowiedzi na awarskie żądania: „Kim jest człowiek, który przyszedł na świat i ogrzewa się w promieniach słońca, a który chce naszą potęgę uczynić sobie poddaną? Zwykliśmy bowiem panować nad cudzymi ziemiami, a nie aby inni nad naszą ziemią panowali. Jesteśmy tego pewni, dopóki są wojny i miecze". ${ }^{3}$ W dłuższej perspektywie okazało się, że Słowianie, przynajmniej ich część musiała poddać się Awarom. Warto jednak odnotować tę wzmiankę Menandra, jako egzemplifikację przekonania o wojowniczej naturze Słowian. ${ }^{4}$

Kilka wieków później, w innym kręgu kulturowym znajdujemy podobne spostrzeżenia. Oto w kontekście opowieści o wojnach ze Słowianami prowadzonych przez króla niemieckiego w X wieku (czasy margrabiego Gerona) wspomina Widukind o częstych wyprawach królewskich na Słowian, które niosły im śmierć, zniszczenie i wszelkie nieszczęścia. „Illi vero nichilominus bellum quam pacem elegerunt omnem

\footnotetext{
2 PROKOPIUSZ Z CEZAREI. $O$ wojnach, Tłumaczenie za BRZÓSTOWSKA, Alina - SWOBODA, Wincenty (ed.): Testimonia najdawniejszych dziejów Słowian. Seria grecka. Zeszyt 2. Pisarze z V-X wieku. Prace Slawistyczne nr 63, Warszawa 1989, s. 64, VII, 22, 2-5.

${ }^{3}$ MENANDER PROTEKTOR. Historia. In: NIEBUHR Bartold Georg (ed.): Corpus Scriptorum Historiae Byzantinae. T. 1, Bonnae 1829, s. 281-444. Tłumaczenie za BRZÓSTOWSKA, A. - SWOBODA, W. (ed.): Testimonia najdawniejszych dziejów Słowian. Seria grecka. Zeszyt 2, s. 126.

${ }^{4} \mathrm{O}$ stereotypach i topicznych określeniach Słowian por. TYSZKIEWICZ, Lech Aleksander: Motywy oceny Słowian w Kronice Thietmara. In: HECK, Roman et al. (ed.): Studia z dziejów kultury i ideologii ofiarowane Ewie Maleczyńskiej w 50 rocznicę pracy dydaktycznej naukowej. Wrocław - Warszawa - Kraków : Zakład Narodowy im. Ossolińskich, 1968, s. 104-118; TYSZKIEWICZ, Lech Aleksander: Z badań nad narodzinami stereotypów Słowian w historiografii zachodniej wczesnego średniowiecza. In: WRZESIŃSKI, Wojciech (ed.): Wokół stereotypów Niemców i Polaków. Acta Universitatis Wratislaviensis 1136, Historia 79, Wrocław 1991, s. 27-47; TYSZKIEWICZ, Lech Aleksander: Slavi genus hominum durum. In: WRZESIŃSKI, Wojciech (ed.): Wokół stereotypów Niemców i Polaków. Acta Universitatis Wratislaviensis 1554, Historia 114, Wrocław 1993, s. 3-14.
} 
miseriam carae libertati postpontes" ${ }^{5}$ Bo też i taki to rodzaj ludzi - wyjaśnia - twardych i uporczywych w pracy, przyzwyczajonych do nędznego pożywienia, a walczących o wolność w obliczu grożącej niewoli. Słowiańskie uwielbienie wojaczki i zgoła niepokojowy charakter przedstawia nam także neutralny światopoglądowo pisarz - sefardyjski Żyd Ibrahim ibn Jakub, tak charakteryzując Słowian: „na ogół Słowianie są skorzy do zaczepki i gwałtowni i gdyby nie ich niezgoda, wywołana mnogością rozwidleń ich gałęzi i podziałów na szczepy, żaden lud nie zdołałby sprostać im w sile."

Co ciekawe, o niechęci do wojen i umiłowaniu pokoju informuje nas tylko jeden przekaz. Piszący w pierwszej połowie VII w. historyk Teofylakt Simokatta, przy okazji opowiadania o wojnie z Awarami za panowania cesarza Maurycego (582 - 602), mającej miejsce zapewne w roku 595 opowiada:

„Trzej ludzie pochodzenia sklawińskiego, nie mający przy sobie żadnego żelaza ani sprzętu bojowego, schwytani zostali przez gwardzistów cesarskich: nieśli jedynie kitary, a niczego poza tym nie mieli. Cesarz wypytywał ich z jakiego są plemienia, gdzie mają swoje siedziby i dlaczego znaleźli się na terytorium rhomajskim. Oni zaś odparli, że pochodzą ze szczepu Sklawinów, mieszkają nad brzegami Oceanu Zachodniego i że chagan aż tam wysłał posłów dla zgromadzenia sił zbrojnych, a przywódcom poszczególnych szczepów ofiarował wielkie dary. Oni jednak wzięli dary, odmówili mu pomocy zbrojnej, twierdząc, że odstraszają ich przestrzenie do przebycia, a do chagana wysłali ich właśnie, obecnie schwytanych, z wymówką, że sami drogę tę odbywać musieli piętnaście miesięcy. Chagan jednak, zapominając o prawach przysługujących posłom, postanowił nie pozwolić im na powrót. A oni zasłyszawszy o narodzie rhomajskim, niezmiernie słynnym z bogactwa i życzliwości, skorzystali z odpowiedniej chwili i przedostali się do Tracji. Noszą zaś kitary, ponieważ nie są przyzwyczajeni odziewać się w zbroje, bo ich ziemia nie zna żelaza i dlatego pozwala im żyć w spokoju bez waśni; grają na lirach, ponieważ nie umieją dąć w surmy bojowe, a ludziom, którzy nigdy nie słyszeli o wojnie, zbyteczne są oczywiście surowsze rodzaje muzyki. Cesarz tedy z wielkim zajęciem słuchał opowieści o tym plemieniu, ugościł łaskawie tych barbarzyńców, a nadziwiwszy się ich wzrostowi i wspaniałej budowie, wyprawił ich do Heraklei". ${ }^{6}$

\footnotetext{
${ }^{5}$ Die Sachsengeschichte des Widukind von Korvei. In: HIRSCH, Paul - LOHMANN, Hans E. (ed.): Monumenta Germaniae Historica. Bd. 60. Hannover 1935, cap. II, 20.

${ }^{6}$ Theophylacti Simocattae Historiarum. In: NIEBUHR Bartold Georg (ed.): VI, 2. Tłumaczenie za BRZÓSTOWSKA, A. - SWOBODA, W. (ed.): Testimonia najdawniejszych dziejów Słowian. Seria grecka. Zeszyt 2, s. 259n.
} 
W poszukiwaniu idealnych Słowian - o wojowniczości i pacyfizmie ...

Relacja tych trzech, pochwyconych dość przypadkowo Sklawenów wywarła, jak słyszymy, spore wrażenie na cesarzu. Ile w niej prawdy tego możemy się tylko domyślać. Można wyrazić przypuszczenie, że ci trzej Słowianie nałgali Rhomajom o obyczajach swych rodaków, a mieli świadomość, że ich opowieści nikt nie będzie w stanie zweryfikować. Czy cesarz im uwierzył, tego Teofylakt Simokatta wprost nie pisze. Co jednak dla nas istotne, $w$ tę relację uwierzyło wielu nowożytnych historyków, przyczyniając się $\mathrm{w}$ dużym stopniu do powstania stereotypu pokojowego Słowianina, któremu obca była wojna i zaborczość, a który ponad wszystko przedkładał spokojną pracę na roli oraz grę na cytrze. Ten opis pokojowej natury ludów słowiańskich jest sprzeczny $\mathrm{z}$ wszystkimi doświadczeniami Rhomajów, wyniesionymi z walk ze Słowianami. Trudności w walce opisują traktaty wojskowe i kronikarze. Zestawiając wiadomości Teofylakta z współczesnym mu opisem Prokopiusza z Cezarei, stwierdzić wypada, że w opisie Słowian zgodni są co do jednego faktu - Słowianie nie noszą zbroi. Prokopiusz pisze: „Stając do walki, na ogół pieszo idą na nieprzyjaciela, mając $\mathrm{w}$ ręku tarczę $\mathrm{i}$ dzidę, pancerza natomiast nigdy nie wdziewają. Niektórzy nie mają ani koszuli, ani płaszcza, lecz jedynie długie spodnie podkasane aż do kroku i tak stają do walki z wrogiem."

Opowieści o trzech Sklawinach zapisanej przez Teofylakta nie sposób traktować poważnie. To swego rodzaju ciekawostka czasów wojennych. Stała się ona jednak jednym z głównych filarów stworzenia obrazu Słowian-pacyfistów. Karierę w nauce i literaturze ten wzorzec zaczyna w XVIII wieku. Znakomicie dopasował go do swej koncepcji historiozoficznej Johann Herder. Ten pochodzący z Prus Wschodnich filozof dał podstawy do romatycznych wizji narodu - jedności pokoleń. Historię pojmował jako continuum, realizację boskich planów. Świat miał opierać się na ładzie, podobnym do tego panującego w przyrodzie - pięknej, wzniosłej i pełnej sensu. Człowiek poprzez rozum i wolność współuczestniczy w dziejach, a przez swe działania stworzył tradycję według Herdera - łańcuchem kultury. Boski plan wobec ludzkości nakazuje zastanowić się przeznaczeniem narodu i jednostki. Naród to jedność pokoleń przeszłych, obecnych i przyszłych.

W swych dociekaniach nad procesem rozwojowym ludzkości, J. Herder wyrażał wiarę w powstanie nowego społeczeństwa, opartego na idei człowieczeństwa, w którym zaistnieją warunki godziwego życia ludzkiego. Wyjątkowe miejsce przypadało w tej wizji narodom słowiańskim, ze względu na ich odpowiedni do nowych, przyszłych warunków, charakter i wartości moralne. Słowianie mimo ucisku niewoli, w jakim żyli, zachowali ową młodzieńczą świeżość, która pomóc im miała w poprowadzeniu ludzkości do nowego człowieczeństwa, czego 
nie zdołali dokonać wcześniej ani Rzymianie ani Germanie. Na historyków słowiańskich mocno musiał oddziaływać opis: „Słowianie osiedlali się wszędzie, by objąć w posiadanie kraje, opuszczone przez inne ludy, by jako osadnicy, pasterze lub rolnicy ziemie te uprawiać i użytkować. Po wszystkich poprzednich spustoszeniach, przemarszach i wędrówkach ich cicha, pracowita działalność przyniosła krajom tym niewątpliwe korzyści. (...) Byli uczynni, gościnni aż do rozrzutności, byli miłośnikami wiejskiej swobody, ale przy tym ulegli i posłuszni, byli wrogami rabunku i grabieży."7 Taki obraz dziejów słowiańskich dawał nadzieję na wspaniałe jutro, w którym dojdzie do odrodzenia narodowych, swojskich elementów kulturowych. Świetlana przyszłość ludów słowiańskich wskazana przez Herdera była szczególnie ważna dla filozofów, historyków czy literatów pochodzących z krajów słowiańskich, a żyjących w I połowie XIX wieku. Tylko jeden naród słowiański - rosyjski posiadał wówczas własne państwo, reszta natomiast znajdowała się pod rosyjskim właśnie, niemieckim, węgierskim czy tureckim panowaniem. Jednocześnie była to podnieta do podjęcia badań nad słowiańską przeszłością. ${ }^{8}$

Zainteresowanie życiem i dziejami dawnych Słowian ma istotne znaczenie dla rozstrzygnięć dotyczących tzw. charakteru narodowego. Oto w czasach Oświecenia rozwija się dość powszechne przekonanie, że każdy naród ma swą duszę, swój charakter, swoje cechy. Wawrzyniec Surowiecki, prekursor polskich badań nad dziejami i kulturą Słowiańszczyzny zaprezentował dość powszechne wówczas przekonanie o istnieniu narodowych cech oraz i dziedziczności. W swej rozprawie, czytanie publicznie w 1809 roku napisał: „Najpóźnieysze pokolenie dziedziczą pospolicie przymioty swych przodków; obyczaie, mniemania, przesądy, oświecenia, wady i cnoty, które dziś władaią naszymi postępkami, biorą częstokroć swe źrzódło z nayodlegleyszych epok nadddziadów."9 Istnieje zatem łączność między współczesnymi a minionymi pokoleniami:

„Aże oni są oycami naszemi, ich sława iest naszą; możemy się nią sprawiedliwie sczycić, bo dla nas samych była przysposobiona; zasługi oyców spadaią na synów." 10 „Wśród najokropniejszych zaburzeń barbarzyństwa, wśród ciemnoty, gwałtów i przemocy powszechnej,

\footnotetext{
${ }^{7}$ HERDER, Johann Gottfried: Wybór pism. Wrocław etc.: Zakład narodowy imienia Ossolińskich, 1987, s. 491n.

${ }^{8}$ BOROŃ, Piotr: Odezwa Towarzystwa Przyjaciół Nauk jako inspiracja badań nad wczesnymi dziejami Polski i Słowiańszczyzny. In: Miscellanea Historico-Archivistica. T. 14, Warszawa 2002, s. 97.

9 SUROWIECKI, Wawrzyniec: Rozprawa o sposobach dopełnienia historii i znajomości dawnych Słowian... czytana na posiedzeniu publicznym Towarzystwa Przyjaciół Nauk, dnia 19 stycznia 1809 roku. In: Rocznik Towarzystwa Warszawskiego Przyjaciół Nauk. T. 8,1812 , s. 85 .

${ }^{10}$ SUROWIECKI, W.: Rozprawa o sposobach, s. 97.
} 
W poszukiwaniu idealnych Słowian - o wojowniczości i pacyfizmie ...

Polacy umieli ciągle utrzymywać powagę szlachetnego i niepoldegłego narodu. Z tej strony ich chwała wcale nie jest wątpliwa, wszystkie podania i ślad ukazują nam ją w każdej epoce. A że oni są ojcami naszemi, ich sława jest naszą, możemy się nią sprawiedliwie szczycić, bo dla nas samych była przysposobiona: zasługi ojców spadają na synów".11

To właśnie w dziejach najwcześniejszych tkwić miał klucz do zrozumienia losów narodu, mianowicie te cechy, które zwano charakterem narodowym. W Polsce szeroka dyskusja o przyczynach upadku państwa akcentowała również ten element - cechy charakterologiczne. ${ }^{12}$ „Charakterem narodowym zwiemy przymioty i wady, czyli raczej dobre i złe nałogi, które, jak okrętem kierujące wiatry na obszernej go wieków pochylają przestrzeni i albo na szczyt chwały wynoszą, albo pogrążają w przepaści" - czytamy w Odezwie Towarzystwa Przyjaciół Nauk. ${ }^{13}$ Badanie owego narodowego charakteru sięgać winno przeszłości najdawniejszej, kiedy formował się ów naród ocierający się z dzikości, jak pisze jeden z wybitniejszych ówczesnych badaczy, Samuel Linde. ${ }^{14}$ Historyzm, rodzący się jako dominujący styl myślenia w XIX stuleciu, w Polsce nabierał szczególnego oblicza, gdyż przeszłość stawała się nie tylko przedmiotem rozważań przyczyn narodowej klęski, jaką były rozbiory i upadek niepodległego państwa, ale też w przeszłości tkwić miały źródła odrodzenia. ${ }^{15}$ Rozważania o przyrodzonym charakterze narodowym stanowiły poważny element propagandy politycznej. W Odezwie Rzq̨du Narodowego do obywateli Litwy, Wołynia, Podola i Ukrainy z 13 maja 1831 roku, tekście jak najbardziej polityczny, z czasów powstania listopadoweho, przeczytać możemy: „Narody nagle i przymusem pierwiastków swego bytu zmieniać nie mogą i nie powinny. Mają one swój klimat, swój przemysł, swoją religię, swoje obyczaje, swój charakter, swój stopień uprawy, swoją historię".16

\footnotetext{
${ }^{11}$ SUROWIECKI, W.: Rozprawa o sposobach, s. 97.

12 WIERZBICKI, Andrzej: Spory o polska duszę. Z zagadnień charakterologii narodowej $w$ historiografii polskiej XIX i XX w. Warszawa : Collegium civitas et al. 1993, s. 30nn.

13 Odezwa Towarzystwa Królewskiego Przyjaciół Nauk w sprawie prospektu Historii Narodu Polskiego. In: KRAUSHAR, Aleksander: Towarzystwo Warszawskie Przyjaciół Nauk 1800-1832 : monografia historyczna osnuta na źródłach archiwalnych. Kraków - Warszawa 1902, t. 2, cz. 2, s. 218-227.

${ }^{14}$ Archiwum Główne Akt Dawnych, Akta Towarzystwa Przyjaciół Nauk, sygn. 25, Raport do St. Staszica w sprawie prospektu historii narodu Polski.

15 WITKOWSKA, Alina: Sławianie, my lubim sielanki. Warszawa : Państwowy Instytut Wydawniczy, 1972, s. 3.

${ }^{16}$ Biblioteka Czartoryskich, rękopis IV, 5275, k. 15. Także wersja dostępna w bibliotece digitalnej Polona: https://polona.pl/item/obywatele-litwy-wolynia-podola-i-ukrainy-bra cia-nasi-inc-rzad-narodowy,NTk5MzEzNjU/0/\#item. [Dostęp 9-01.2020].
} 
Tym sposobem pradawna Słowiańszczyzna stawała się w wyobraźni wielu historyków pierwszej połowy XIX stulecia (bez określania ideowych podstaw przez nich reprezentowanych - oświeceniowych czy romantycznych) zjawiskiem wręcz sakralnym, którego badanie i opisywanie było obowiązkiem o charakterze nadnaturalnym. ${ }^{17}$ Wawrzyniec Surowiecki ten obowiązek rozumiał jako nabyty z racji urodzenia, wspólnoty etnicznej: „Tak, to jest prawda, że trzeba być Słowianinem, ażeby poznać $i$ odmalować Słowianina".18 Pomiędzy badaczem a badanym przedmiotem istnieje zatem silny związek uczuciowy i bliskość etniczna. Co ciekawe, słowa te napisał człowiek o bardzo trzeźwych poglądach na świat, wychowany w duchu oświeceniowego racjonalizmu. $\mathrm{W}$ tej samej pracy przedstawia bardzo istotny dla badacza przeszłości postulat: historyk, gdy nie chce bez pożytku zapuszczać się w świat dawny, musi wprzód zapomnieć o tym wszystkim, co go dziś otacza... ${ }^{19}$ Według Surowieckiego badacz nie może zapominać o tym, kim jest i dla kogo pisze.

Utożsamianie się $\mathrm{z}$ przeszłością zauważyć można także $\mathrm{w}$ pracach Józefa Maksymiliana Ossolińskiego. Według niego, w badaniach historycznych staramy się objaśniać, „naydawniejszy stan nasz”. Nasz - czyli Polaków, a szerzej Słowian. W jego wypowiedziach zauważyć można znaczącą identyfikację z dziejami Słowian. ${ }^{20}$ Badania historyczne mają jak najbardziej utylitarny cel - poznanie przeszłości nas samych. Dzieje najdawniejsze, wręcz bajeczne mówić mają przede wszystkim o nas, przeglądamy się w nich jak w zwierciadle.

Przekonanie o pokojowym nastawieniu Słowian było powszechne. Historyk nietuzinkowy i zwykle bardzo krytyczny - Jerzy Samuel Bandtkie pisał, że Słowianie znajdowali się pod panowaniem Gotów, Hunów, w końcu Awarów. „czego tym łatwiej mogli dokonać, gdyż większa część Słowian była bezbronna. Podobno dopiero w VI wieku zaczęli Słowianie brać się do oręża. Może bydź, że wtedy dopiero nastali u nich wodzowie, wojewodowie, książęta (...)"21 Dopiero udział w wojnach zmienia pierwotny ustrój gminowładny w arystokratyczny, a nastawiony dotąd pokojowo i zajęty uprawą roli lud wkroczył do historii.

Aby nie koncentrować się tylko na polskich historykach, oddajmy głos ojcu-budzicielowi czeskiej i słowackiej nacji, pochodzącemu z dzi-

\footnotetext{
17 WITKOWSKA, A.: Sławianie, my lubim sielanki, s. 29.

${ }^{18}$ SUROWIECKI, W.: Rozprawa o sposobach, s. 95.

${ }^{19}$ SUROWIECKI, W.: Rozprawa o sposobach, s. 90.

20 OSSOLIŃSKI, Józef Maksymilian: Początki Sławian. Rozprawy 1-4. In: Czasopismo Naukowe od Zakładu Narodowego im. Ossolińskich. Vol 1.1831, s. 11.

${ }^{21}$ BANDTKIE, Jerzy Samuel: Dzieje królestwa polskiego, t. 1. Wrocław : Wydawnictwo B. Korn, 1820, s. 53. Także BANDTKIE, Jerzy Samuel: Dzieje narodu polskiego, t. 1. Wrocław: Wydawnictwo W. B. Korn, 1835, s. 39.
} 
W poszukiwaniu idealnych Słowian - o wojowniczości i pacyfizmie ...

siejszej Słowacji, Pawłowi Szafarzykowi. ${ }^{22}$ W swej pracy o Słowiańskich starożytnościach pisze on tak: „Dawne dzieje daleko więcej nam pamiątek zachowały o narodach bojowych i łupieżczych, jakiemi byli Celtowie, Sarmaci i Germanie, niż o narodach spokojnych i rolniczych, do jakich należeli Słowianie”. ${ }^{23}$ „Dawni Słowianie, jeśli dobrze ich dzieje rozumiemy, jako ludzie łagodni, pokój, orzbę, rzemiosła i kupiectwo miłujący, prowadząć ciągle żywot obronny niż podbojowy, u obcych historyków, mianowicie greckich i rzymskich, wlokących się zwykle za szczękiem oręża i wojny, a mało ceniących cichą wielkość narodów, daleko mniej zasłynęli niż inne drapieżne, świat niszczące narody (...) jest to odwieczna wada dziejów, że obyczajem pospólstwa zawsze chętniej zwracają wzrok swój na zewnętrzne, głośne krwawe i silnie zmysły uderzające czyny, niż na bogumiłe zjawiska wewnętrznego żywota narodów. Słowianie dopiero przykładem Hunów, Bułgarów zagrzani, częścią krzywdą doznawana od sąsiadów przymuszeni, zaczynają toczyć krwawe boje z Grekami nad Dunajem - wtedy stają się przedmiotem bacznej uwagi pisarzy". (...) Jednakże przy wszelkiej skłonności w swojej do spokojnego żywota i do skromnych zatrudnień nie byli dawni Słowianie do sztuki wojennej naprost niesposobni, i nie należy domniemywać się, że w ich ojczyźnie ciągle się bez bojów obeszło, że oni każdemu ciemiężcy nastawiali karki swoje, bez odporu wprzęgając je w niewolę i jarzmo. Umieli Słowianie, gdzie tego potrzeba wymagała, tak mężnie władać bronią jak i inni jacykolwiek najzwyczajniejszy ich nieprzyjaciele. Różnica między nimi a ich nieprzyjaciółmi była jedynie ta, że u nich wojna nie była rzemiosłem ku powszedniemu pożywieniu, jak u Sarmatów Gotów, Wandalów i innych, że broń nosili tylko do obrony, nigdy napaści. ${ }^{24}$

To bardzo ważne stwierdzenie, kształtujące wyobraźnię czytelników - nasi przodkowie nie unikali wojny, ale miłując pokój, toczyli tylko wojny obronne, czyli sprawiedliwe. To zagadnienie samo w sobie, rozważane w literaturze, poczynając od Cycerona czy św. Augustyna. W usprawiedliwianiu wojny często sięgano po kategorię wojny obronnej. Tu wskazano na przyrodzone cechy Słowian, nie pragnących cudzego, ale broniących swego. Wizja Szafarzyka koresponduje z uwagą zamieszczoną przez W. Surowieckiego, o tym, że „Nareszcie inne zdobywcze narody wprawione do życie wojennego, przelatywały z mieysca na

\footnotetext{
22 KUTNAR, František - MAREK, Jaroslav: Přehledné dějiny českého a slovenského dějepisectví. Od počatků národní kultury až do sklonku třicátých let 20. století. Praha : Nakladatelství Lidové noviny, 1997, s. 230-234.

23 SZAFARZYK, Paweł J.: Starożytności Słowiańskie. Oddział dziejopisny, cz. 1. Poznań : Wydawnictwo W. Stefańskiego, 1844, s. 371.

${ }^{24}$ SZAFARZYK, P. J.: Starożytności Słowiańskie, s. 684.
} 
mieysce w przerażających tłumach, szukając nieprzyjaciół na to tylko, żeby ich gnębić, i wydzierać gotowe łupy; Słowianie niestraszni z oręża, łagodni z przyrodzenia, przez wolne wędrówki szukali jedynie ziemi, którą by potem własnego czoła upłodniąc mogli." 25

Po wędrówce Słowian nie zadali oni ostatecznego ciosu Cesarstwu wschodniemu „częścią przywiązania iego do rządu gminowładnego, który nie dozwalał zgromadzać się w znacznieyszei liczbie pod iednego Wodza, częścią mnieyszei skłonności szukania łupów bogatych niż osad spokoynych.” Po zajęciu niezmierzonych krain, Słowianie „nie myśleli iuż o niczem więcey, iak tylko o uprawie tey nowey dziedziny i o obronie iey od wszelkiey napaści obcey". 26

Wizje pokojowo nastawionych Słowian nie znalazły jednak powszechnego uznania. Obraz Słowianina - wojownika, aczkolwiek przysłonięty przez romantycznych zwolenników Słowianina-pacyfisty pojawia się u różnych pisarzy. Czasem widać, że przekonanie, że wojowniczość przystoi Słowianom niczym żałoba Elektrze, jest bezdyskusyjne. Jeden ze światlejszych i wyjątkowo trzeźwo myślących intelektualistów początku XIX w., Aleksander Sapieha w swych relacjach z podróży do krajów słowiańskich zdaje się nie znać zupełnie obowiązujących powszechnie wizji Herderowskich.

Aczkolwiek Sapiehę uznaje się dość powszechnie za prekursora słowianofilstwa, a jednym z głównych inspiratorów słowianofilstwa był Herder, to nic w pracach Sapiehy nie wskazuje, aby czerpał z jako wizji przeszłości ludów słowiańskich. Wręcz przeciwnie, jego wyobrażenie Słowian odbiega od Herdera. Różnica tkwi w podejściu do spraw wojny i pokoju. Herder przedstawia Słowian jako naród nastawiony zdecydowanie pokojowo, rysuje wręcz obraz słowiańskiej sielanki. Słowianie to lud miłujący pokój. U Sapiehy natomiast Słowianie to lud rozmiłowany w wojnie i broni. Wojowniczość jest dla niego jednym z głównych wyznaczników słowiańskości.

Opisując różnych mieszkańców wybrzeży Adriatyku, zwraca Sapieha często uwagę na ich strój i obyczaje, szukając elementów słowiańskich. W charakterystyce mieszkańców wyspy Velia - dziś modny wśród turystów Krk - miał wątpliwości, co do ich słowiańskiego pochodzenia. Przyczyną tych wątpliwości jest wstręt tamtejszych mieszkańców do spraw wojskowych. Pokolenie Słowian miały być bitne z samej swej natury, stąd mieszkańcy Krk mogli według Sapiehy pochodzić od Sarmatów, gdyż ci również nosili według Strabona czarne

\footnotetext{
25 SUROWIECKI, Wawrzyniec: Śledzenie Początków Narodów Słowiańskich: rosprawa czytana na publiczném posiedzeniu Królewsko-Warszawskiego Towarzystwa Przyjaciót Nauk. Warszawa 1824, s. 6.

${ }^{26}$ SUROWIECKI, W.: Rozprawa o sposobach, s. 96.
} 
W poszukiwaniu idealnych Słowian - o wojowniczości i pacyfizmie ...

odzienie. Te wyjaśnienia wydają się dziś mocno naiwne, ale wówczas uważano je za normalne. Dość często w Podróżach ... pojawia się przekonanie, że wojowniczość jest jedną z głównych cech ludów słowiańskich. Noszenie broni jest jednym z głównych oznak tej cechy. ${ }^{27}$

Co ciekawe wątek wojowniczości Słowian pojawił się także w apokryfach. W Słowie o pułku Igora przedstawia wzorzec wojowniczości - miłości do wojny. ${ }^{28}$ Poemat ten kończy się wezwaniem: „Niech żyją książęta i drużyna, walcząca za chrześcijan z wojskami pohańców. Sława książętom a drużynie". Zwycięstwo nad Połowcami opisywane w kontekście ogromnych zdobyczy i chwały dla Igora i jego wojsk: „Zgnietli niewierne pułki połowieckie i rozsypawszy się jak strzały po stepie, zagarnęli piękne dziewczęta połowieckie, a z nimi tkaniny i drogie złotogłowia; okryciami, opończami i kozuchami zaczęli mosty mościć na błotach i grzęzawiskach - wszelkimi ubiorami połowieckimi. Czerwony znak, biała chorągiew, czerwony buńczuk, srebrne drzewce - dla mężnego Światosławowicza". ${ }^{29}$ Wojny Rusinów przyrównane są w tym apokryfie do czasów trojańskich, ewidentnie wskazując na wątek rycersko - wojenny.

Przekonanie o wojowniczości Słowian odnaleźć można w innych apokryfach. Staroczeskie pieśni Vaclawa Hanki można nazwać poezją rycerską z doby pogaństwa. Inny twórca fałszerstw, polski szlachcic Jan Antosewicz, nie mając pewności, jak to z duchem narodowym Słowian było, sięgnął do wątku podboju, gnuśnych pacyfistów, przez rzutkich wojowniczych Lechitów. Ponieważ musiał się zmierzyć z panującym dość powszechnie przekonaniem o pokojowym nastawieniu Słowian oparł się w swym dziele na apokryfie - pismach wojewodów Żelizów (prawdopodobnie przez niego samego sprokurowanym), i wyjaśnił dwoistość lechickiej (nie słowiańskiej) natury wskazując na różnych przodków. Oto pokojowo nastawione ludy Wandalów, Gotów, Sarmatów i innych, zamieszkujące kraj nad Wisłą, zostały podbite przez znakomicie zorganizowanych i zamiłowanych w wojaczce Słowian przywiedzionych tu przez Lecha. ${ }^{30}$

\footnotetext{
27 SAPIEHA, Aleksander: Podróże w krajach słowiańskich odbywane. Wrocław etc : Zakład Narodowy imienia Ossolińskich, 1983, s. 60. Szerzej ten wątek w pracy BOROŃ, Piotr: Myśl historyczna w „Podróżach w krajach sławiańskich Aleksandra księcia Sapiehy”. In: STĘPNIK, Krzysztof (ed.): Sapiehowie epoki Kodnia i Krasiczyna. Lublin : Wydawnictwo Uniwersytetu Marii Curie Skłodowskiej, 2007, s. 503-516.

${ }^{28}$ Przychylam się do zdania tej grupy naukowców, którzy uznają tekst poematu za apokryf. Opinie w tej kwestii omówił HODANA, Tomasz: Najnowsze spory o autentyczność „Słowa o wyprawie Igora”. In: Przegląd Rusycystyczny. 2011, nr 3, s. 5-32.

${ }^{29}$ OBRĘBSKA-JABŁOŃSKA, Antonia (ed.): Słowo o wyprawie Igora. Warszawa : Państwowy Instytut Wydawniczy, 1954, s. 156.

${ }^{30}$ BOROŃ, Piotr: „Przeciw upodleniu dziejów Polski i w obronie prawdy” - Jana Andraulta de Buy Antosewicza Obrona Kadłubka i Długosza. In: WISZEWSKI, Przemysław - ROSIK, Stanisław (ed.): Cor Hominis. Wielkie namiętności w dziejach, źródłach i studiach nad
} 
Antosewicz zamienił siedemnastowieczną wizję pochodzenia narodu szlacheckiego od Sarmatów, zdobywców kraju nadwiślańskiego, zamieszkałego przez pokojowo nastawionych, gnuśnych nieco rolników na skonstruowaną przez siebie opowieść o Słowianach podbijających Sarmatów. Wzorzec Słowianina - pacyfisty był mu obcy, hołdował etosowi wojownika, zatem musiał wyjaśnić rozbieżności między swymi wyobrażeniami a stanem faktycznym, czyli aktualnym stanem chłopstwa. Teoria podboju była tu bardzo przydatna. Nie można tu także wykluczyć inspiracji literackiej, przez dość szeroko rozpowszechniony wówczas poemat biskupa Jana Pawła Woronicza - Lechiada. Woronicz zaczynał swój poemat:

„Niepożyci wiekami Sławiańscy Lachowie!

Szerokowładnych w świecie Sarmatów wnukowie,

Godni w samych zwaliskach litości i cześci!

Posłuchajcie o Lechu starożytnej wieści,

Jako do was z kroackiej przeszedłszy ziemicy,

Dał wam imię i mury pierwszej wzniósł stolicy,

A wspólnej krwi Heneckiej żeniąc z wami początek

Lackiej gałęzi Sławian zaszczepił początek"31

Ten początek ludu, składającego się z dwu różnych „charakterologicznie" składników wyjaśniać miał pomieszanie wzorców - wojownika i miłośnika pokoju.

Tak jak zwolennicy Słowian - wojowników posługiwali się teorią podboju, tak samo wykorzystana została przez osoby hołdujące pokojowej, pradziejowej sielance. To zwolennicy pokojowego gminowładztwa musieli wyjaśnić, dlaczego nasi przodkowie przestali żyć w pokoju, rządzić się i rozsądzać spory na demokratycznych wiecach. I tu teoria najazdu okazała się idealnie wpisywać w określoną wizją przeszłości. Geneza państw słowiańskich oparta była bowiem na podboju - najeździe brutalnych, wojowniczych plemion czy grup, które uzależniły pokojowo nastawionych, łagodnych Słowian. Teoria podboju miała w historiografii europejskiej doby romantyzmu swoje określone miejsce. Wypracowali jej podstawy tacy uczeni jak Francois Guizot i Augustin Thierry. ${ }^{32} \mathrm{~W}$ polskiej i rosyjskiej historiografii teoria podboju posiadała jednak zupełnie inne, wcześniejsze umocowanie. Najazd i podbój był podstawą ideologii szlacheckiego sarmatyzmu w Polsce, zaś w Rosji niepodważalny był w czasach o których mowa, udział Normanów w

przeszłościq. Wrocław 2007, Acta Universitatis Wratislaviensis 3049, Historia t. 176, s. 101-108.

31 WORONICZ, Jan Paweł: Poezye. T. 1. Kraków : Wydawnictwo J. Czecha, 1832, s. 149.

32 WIERZBICKI, Andrzej: Historiografia polska doby romantyzmu. Wrocław : Fundacja na rzecz Nauki Polskiej, 1999, s. 428. 
W poszukiwaniu idealnych Słowian - o wojowniczości i pacyfizmie ...

kształtowaniu się państwa. ${ }^{33}$ Wystarczyło tylko nadać nowe znaczenia poszczególnym warstwom społecznym. Ojciec polskiej historiografii, Joachim Lelewel stworzył teorię najazdu gminu kmiecego przez Lechitów, przodków szlachty. To Lechici podbili ten „łagodny w usposobieniach lud".34 Ten wątek wykorzystany został przez Vaclava Hankę w osławionym czeskim apokryfie - Rękopisie Zielonogórskim, gdzie w „Sądzie Libuszy" Lechici występują jako warstwa społeczna. Teoria podboju w polskiej literaturze XIX wieku była adoptowana przez coraz to nowych badaczy. Fryderyk Henryk Lewestam stworzył teorię najazdu celtyckiego, ${ }^{35}$ zaś August Bielowski teorię illiryjską. ${ }^{36}$ Zawsze skory do puszczania wodzów fantazji Karol Szajnocha sięgnął natomiast po wątek normański. ${ }^{37}$ Lechickie teorie najazdu sfalsyfikował ostatecznie dopiero pod koniec XIX wieku Antoni Małecki. ${ }^{38}$

Warto w tym miejscu wspomnieć o najwartościowszym (oczywiście od względem literackim) dziele prezentującym teorię podboju. Mam tu na myśli tragedię Juliusza Słowackiego „Lilla Weneda”. Wenedzi, rdzenni mieszkańcy okolic Gopła, a pewnie i całej Polski zostali najechani przez Lechitów. Tych jednak Słowacki odmalował w wyjątkowo czarnych barwach. To tak naprawdę brutalni, nieokrzesani wojownicy, w których opisie łączą się elementy zaczerpnięte z wyobrażeń rzymskich o Celtach i chrześcijańskich o Normanach.

Ich charakterystykę Słowacki (nb. dobry znajomy Lewestama) ${ }^{39}$ wkłada w usta jednego z bohaterów - Ślaza, który w IV akcie na pytanie czy jest Lechitą, odpowiada:

„Lecz mówić, że ja Lechita! — mnie? — w oczy! -

Gdybym nie mienił to być uchybieniem,

Plunąłbym w oczy temu, kto zapytał,

Czy ja Lechita. - Cóż to? czy mi z oczu

Patrzy gburostwo, pijaństwo, obżarstwo,

Siedem śmiertelnych grzechów, gust do wrzasku,

\footnotetext{
33 АЛПАТОВ, Михаил Антонович: Русская историческая мысль и Западная Европа (XVII - первая четверть XVIII века). Москва : Издательство “Наука”, 1985.

${ }^{34}$ LELEWEL, Joachim: Historyczny rozbiór prawodawstwa polskiego cywilnego i kryminalnego do czasów jagiellońskich. In: Polska wieków średnich czyli $w$ dziejach narodowych polskich postrzeżenia, t. 3. Poznań : Wydawnictwo J. K. Żupańskiego, 1851, s. 15.

${ }^{35}$ LEWESTAM, Fryderyk Henryk: Pierwotne dzieje Polski. Warszawa 1841.

36 BIELOWSKI, August: Wstęp krytyczny do dziejów Polski. Lwów : Zakład Narodowy imienia Ossolińskich, 1850.

37 SZAJNOCHA, Karol: Lechicki początek Polski. Szkic historyczny. Lwów : Wydawnictwo Karola Wilda, 1858.

38 MAŁECKI, Antoni: Lechici w świetle historycznej krytyki. Lwów : Zakład Narodowy imienia Ossolińskich, 1897.

39 SAWRYMOWICZ, Eugeniusz: Wstęp. In: SŁOWACKI, Juliusz: Lilla Weneda. Wrocław : Ossolineum, 1954, s. 10.
} 
Piotr Boroń

Do ukwaszonych ogórków, do herbów;

Zwyczaj przysięgać in verba magistri;

Owczarstwo - czy to wszystko mam na twarzy?

Jeśli tak, wodą mię zlejcie gorącą,

Niechaj oblezie ze mnie pierwsza skóra." (Lilla Weneda, akt IV)

Niepochlebny to obraz dominujących odtąd w Polsce Lechitów, a biorąc pod uwagę powszechną wiarę $\mathrm{w}$ charakter narodowy, także ich potomków - polską szlachtę.

Teoria najazdu, jak zatem widać, mogła być wykorzystywana przez zwolenników różnych ideologii. I nieważne jak nazywano dawnych Słowian, zawsze gdz u źródeł przekonania o ich wojowniczej czy pacyfistycznie łagodnej naturze stały potrzeby współczesności, a wiedza o przeszłości miała dostarczyć argumentów. Co jednak szczególnie istotne, podziały wśród historyków, często pojawiające się w opracowaniach z dziedziny historii historiografii wydają się zupełnie nieprzydatne przy wskazywaniu zwolenników określonych tez czy teorii. Mam tu na myśli podziały na monarchistów i republikanów, lelewelistów i antylelewelistów, optymistów i pesymistów itp. Wizja Słowianina jako wojownika bądź pacyfisty zależała od indywidualnych wizji poszczególnych autorów, ich przekonań, bądź potrzeb współczesności.

Zamykając problem zróżnicowania wizji pradawnej Słowiańszczyzny, należy zauważyć, że zmiana w obrazie tego ludu dokonała się w drugiej połowie XIX wieku. Romantyczna idylla i sielanka zostały porzucona. Na skutek przemian, które dokonały się w polskiej nauce historycznej $\mathrm{w}$ latach sześćdziesiątych i siedemdziesiątych XIX wieku doszło do powstania nowej, „krytycznej szkoły historycznej”. ${ }^{40} \mathrm{~W}$ przeszłość odeszły (a przynajmniej deklarowano ich odejście) wyobrażenia o charakterze narodowym. W scjentystycznym sposobie pojmowania świata naród był sumą jednostek, nie mógł więc posiadać „duszy” czy charakteru. ${ }^{41}$ Nie znaczy to jednak, że historycy zerwali z tworzeniem stereotypowych obrazów. Zmieniły się jedynie sposoby opisywania przeszłości. Słowianie według Władysława Smoleńskiego, prezentującego szerokiej publiczności dzieje narodu polskiego byli: niesforni,

\footnotetext{
40 GRABSKI, Andrzej Feliks: Orientacje polskiej myśli historycznej. Studia i rozważania. Warszawa : Państwowe Wydawnictwo Naukowe, 1972, s. 215n; MATERNICKI, Jerzy: Historia i życie narodu. Poglądy i postawy historyków polskich XIX i XX wieku. Rzeszów : Wydawnictwo Uniwersytetu Rzeszowskiego, 2009, s. 134n.

${ }^{41}$ MODZELEWSKI, Wojciech: Naród i postęp. Problematyka narodowa w ideologii i myśli społecznej pozytywistów warszawskich. Warszawa : Państwowe Wydawnictwo Naukowe, 1977, s. 130; WIERZBICKI, Andrzej: Spory o polskq duszę. Z zagadnień charakterologii narodowej w historiografii polskiej XIX i XX wieku. Warszawa : Collegium civitas etc.: 2010, s. 189 n.
} 
W poszukiwaniu idealnych Słowian - o wojowniczości i pacyfizmie ...

leniwi, lekkomyślni, niedbali o przyszłość. Ociężali z natury, z trudnością zdobywali się na działanie i łatwo wpadali w apatię ${ }^{42}$. Fakt, że jak pisał Smoleński, nie mieli skłonności do wojny, ${ }^{43}$ nie był skutkiem przyjęcia pewnej, pacyfistycznej wizji Słowian. To efekt postrzegania Słowian niemal zgodnie z tezą zaprezentowaną przez Jana Peiskera, jako zapóźnionego cywilizacyjnie ludu, do którego wyjątkowo późno docierała cywilizacja. Romantyczna wizja ludu, nosiciela wszystkich cnót odeszła w przeszłość, zastąpił ją nakaz niesienia oświaty. W związku z odejściem od społecznie zaangażowanej nauki historycznej, zmieniło się także nastawienie do problemu charakteru narodowego. Krytyczne stanowisko Smoleńskiego wobec pradawnych Słowian nie było wyjątkiem. Podobne opinie przedstawiało wielu innych historyków. Taki obraz docierał wreszcie do szerokich mas. Taki właśnie obraz Słowian przynosi nam szeroko rozpowszechniona praca Michała Bobrzyńskiego „Dzieje Polski w zarysie”. Słowianie przedstawiono tam jako lud z natury pokojowy, o niewielkich zdolnościach organizacyjnych. Nastawiona na pokojowe trwanie Słowiańszczyzna nie była zdolne według Bobrzyńskiego do poważniejszych działań organizacyjnych. Pisze on, że „najłatwiej organizowała się luźna rzesza słowiańskich ludów w silny naród i państwo tam, gdzie wskutek podbojów dostała się do krwi słowiańskiej przymieszka jakiejś krwi obcej, pochopniejszej do życia politycznego, do którego Słowianie wskutek tradycyjnej swojej niezgody i przesadnego zamiłowania wolności nie byli jeszcze dojrzali". ${ }^{4}$

Pod koniec XIX stulecia zniknął z kart prac historycznych Słowianin - ideowy pacyfista, sięgający po broń tylko dla obrony. Pojawił się obraz leniwego, apatycznego i lekkomyślnego przodka, którego nie interesuje wojna, który łatwo poddaje się w niewolę, wreszcie zupełnie nie myśli o jutrze. Pomimo deklaracji „scjentystycznych" nie zanikły stereotypy i przekonania o duchu czy charakterze narodowym. Literatura i historiografia mocno ulegały pewnym powszechnym przekonaniom, przejmując i przekazując dalej wypracowane wcześniej wizje. Można tu powtórzyć opinię wyrażoną kiedyś przez Zbigniewa Zielonkę: „Stereotypy pojęć i sądów unoszą się w powietrzu niby bakterie, które wchłaniamy nie wiedząc jak i kiedy" 45 Zapewne podobne stereotypowe opinie pojawiały się w historiografii XX-wiecznej, obecne są także współcześnie, jakkolwiek boleśnie dla nas by to nie brzmiało. W znacznym stop-

\footnotetext{
42 SMOLEŃSKI, Władysław: Dzieje narodu polskiego. Wykład popularny na podstawie ostatnich badań naukowych. Cz. 1. Warszawa 1898, s. 15.

${ }^{43}$ SMOLEŃSKI, Władysław: Historia Polski. Warszawa etc.: Gebethner i Wolff, 1925, s. 18.

${ }^{44}$ BOBRZYŃSKI, Michał: Dzieje Polski w zarysie. Warszawa : Państwowy Instytut Wydawniczy, 1974, s. 77.

45 ZIELONKA, Zbigniew: Henryk Prawy. Katowice: Wydawnictwo Śląsk, 1982, s. 6.
} 
niu można zgodzić się w Franklinem Ankersmitem, twierdzącym że „historia to malowanie obrazów pobudzających wyobraźnię czytelnika". ${ }^{46}$ Nie da się ukryć, że charakterystyki Słowian, zarówno te średniowieczne (mówiąc brzydko źródłowe), jak też opisy historyków pobudzają wyobraźnię czytelnika. Z realnymi Słowianami nie mają jednak wiele wspólnego. Pytanie, czy Słowianie byli miłośnikami pokoju czy też wojownikami wydaje się dziś dość naiwne. W obrazach tworzonych przez historyków można jednak odnaleźć odpowiedź. Nie są to jednak Słowianie realni, a jedynie wyobrażeni. Pacyfiści czy wojownicy - wydaje się, że wszystko zależy tego, jakimi będziemy ich ujrzeć. Szukając wzorcowych Słowian, poszukując prawdy o ich stosunku do wojny i pokoju odnajdujemy przede wszystkim wizje historyczne i literackie. Czyli każdy ma takiego Słowianina, jakiego sobie wyobrazi.

\section{Zhrnutie:}

\section{Hladanie ideálnych Slovanov - o bojovnosti a pacifizme ako o zna- koch národného charakteru vo výskumoch pol'skej historiografie v 19. storočí}

Článok predstavuje vznik dvoch rôznych stereotypov starých Slovanov ako bojovných l'udí a pacifistov. Na základe pol'skej historiografie 19. storočia sa ukázalo, ako sa vhodný stereotyp použil pri historiografickej alebo literárnej reprezentácii starých Slovanov. Východiskom pre stanovisko mnohých historikov boli historické pramene zo 6. - 7. storočia, ktoré predstavovali Slovanov ako bojovníkov, ako aj jedna informácia o mierumilovnom postoji tohto l'udu. Bola ňou správa Theofylakta Simokatta, ktorá získala uznanie mnohých vedcov žijúcich v 18. a 19. storočí, podl'a romantickej vízie Slovanov založenej na historiozofii J. G. Herdera. Článok sa odvoláva na opačné teórie Aleksandra Sapiehu alebo Jana Pawla Woronicza. Pokúsil sa tiež zosúladit' dva protichodné pohl'ady na starých Slovanov v teórii dobývania, všeobecne prijatej v 19. storočí.

\footnotetext{
${ }^{46}$ ANKERSMIT, Frank Rudolf: History and tropology History and Tropology. The Rise and Fall of Metaphor. Berkeley - Los Angeles - Oxford : University of California Press, 1994; RADOMSKI, Andrzej: Sztuka jako źródło do badania historii. Czy historiografia jest sztuką? (na przykładzie literatury). In: Kultura i Historia. 2001, nr 1; ANKERSMIT, Franklin: Narracja jako przedstawienie. In: POMORSKI, Jan (ed.): Metodologiczne problemy narracji historycznej. Lublin 1990.
} 